\title{
Mollusks associated with the Avicennia schaueriana (Magnoliophyta: Acanthaceae) roots of a hypersaline estuary in northeastern Brazil
}

\author{
Moluscos associados a raízes de Avicennia schaueriana (Magnoliophyta: Acanthaceae) em \\ um estuário hipersalino no nordeste do Brasil
}

\author{
Ana Priscila Amancio Muniz ${ }^{1}$ (D), Rafaela Cristina de Souza Duarte ${ }^{1,2 *}$ (D), \\ Ellori Laíse Silva Mota ${ }^{1,2}$ (D), Jessica de Oliveira Lima ${ }^{1}$ (D) and Thelma Lúcia Pereira Dias ${ }^{1}$ (D) \\ ${ }^{1}$ Laboratório de Biologia Marinha, Departamento de Biologia, Universidade Estadual da Paraíba - \\ UEPB, Campus I, Rua das Baraúnas, 351, CEP 58429-500, Campina Grande, PB, Brasil \\ ${ }^{2}$ Programa de Pós-graduação em Ciências Biológicas (Zoologia), Departamento de Sistemática \\ e Ecologia, Universidade Federal da Paraíba - UFPB, Campus I, Cidade Universitária, s/n, \\ CEP 58051-085, João Pessoa, PB, Brasil \\ *e-mail: rafaelacs.duarte@yahoo.com.br
}

Cite as: Muniz, A.P.A. et al. Mollusks associated with the Avicennia schaueriana (Magnoliophyta: Acanthaceae) roots of a hypersaline estuary in northeastern Brazil. Acta Limnologica Brasiliensia, 2019, vol. 31, e16.

\begin{abstract}
Aim: Avicennia schaeuriana is one of the six species that composes the mangrove forests of Brazil and form mangrove fringes along waterways. The mangrove-roots of the $A$. schaeuriana act as one of the microhabitats used by the invertebrate biodiversity of the estuarine ecosystem. The present note aimed to inventory the malacofauna associated with roots of Avicennia schaueriana of the hypersaline and inverse estuary, highlighting variations in abundance and diversity along a salinity gradient and different seasonal periods. Methods: Three sampling stations were delineated along the course of the estuary. At each station 3 transects of 10 meters were placed, and for each of them 3 sample points were selected, and at each point 3 samples of roots of $A$. schaueriana were obtained. A total of 108 samples were stored in plastic bags containing $4 \%$ formaldehyde and subsequently passed through a screening process, with identification of the associated specimens with the lowest possible taxonomic level. Results: A total of 171 specimens was recorded, belonging to 10 species, 7 families, and 9 genera of the Bivalvia and Gastropoda classes. The abundance of the specimens differed between the seasonal periods analyzed. Conclusions: The highest species richness and abundance of organisms in the rainy period allows inferences about the importance of the estuarine water cycle in regulating the biodiversity of these environments. Thus, the importance of the maintenance and protection of the mangrove forests composed of $A$. schaneriana, as well as the need for more in-depth studies becomes evident.
\end{abstract}

Keywords: mangrove forest; invertebrates; estuary; gastropods.

Resumo: Objetivo: Avicennia schaeuriana é uma das seis espécies que compõem as florestas de mangue do Brasil e formam franjas de mangue ao longo dos cursos d'água, sendo diretamente influenciadas pela maré. As raízes do mangue A. schaeuriana atuam como um dos microhábitats utilizados pela biodiversidade de invertebrados do ecossistema estuarino. Este estudo objetivou inventariar a malacofauna associada às raízes de Avicennia schaueriana em um estuário hipersalino e inverso, destacando variaçóes na abundância e diversidade ao longo de um gradiente de salinidade e em períodos sazonais distintos. Métodos: Foram delimitadas três estaçóes amostrais ao longo do curso 
do estuário. Em cada estação foram posicionados 3 transectos de 10 metros paralelos a margem e para cada um deles foram sorteados previamente 3 pontos amostrais aleatórios e em cada ponto foram obtidas 3 amostras de raízes de $A$. schaueriana. Um total de 108 amostras foram acondicionadas em sacos plásticos contendo formol a $4 \%$ e posteriormente passaram por processo de triagem e identificação dos espécimes associados até o menor nível taxonômico possível. Resultados: Uma abundância total de 171 indivíduos foi registrada, distribuída entre 10 espécies, 7 famílias e 9 gêneros, das classes Bivalvia e Gastropoda. A abundância dos espécimes diferiu entre os períodos sazonais e entre as estaçôes de amostragem ao longo do gradiente de salinidade. Conclusóes: A maior riqueza de espécies e abundância de organismos no período chuvoso permite inferir sobre a importância do ciclo hidrológico estuarino na regulação da biodiversidade deste ambiente. O presente estudo evidencia a importância da manutenção e proteção das florestas de mangue compostas por $A$. schaueriana, bem como a necessidade da realização de estudos mais aprofundados.

Palavras-chave: florestas de mangue; invertebrados; estuário; gastrópodes.

Mangrove environments are characterized by a structural complexity that provides stable conditions essential for the maintenance of estuarine ecological communities (Feller et al., 2010). The aerial mangrove-roots system, arranged in elevation to the substrate, significantly increases the architecture of mangrove forests, providing a habitat for colonization, feeding, and protection of several organisms (Nagelkerken et al., 2008). Avicennia schaeuriana Stapf \& Leechman is one of the six species that composes the mangrove forests of Brazil and form mangrove fringes along waterways, which are directly influenced by the tide (ICMBio, 2018).

The mangrove-roots of the $A$. schaeuriana act as one of the microhabitats used by the invertebrate biodiversity of the estuarine ecosystem. The groups of organisms that compose this biodiversity are mainly macrobentonic organisms, polychaetes, mollusks, and crustaceans (Samidurai et al., 2012). These organisms actively participate in the mangrove food web, linking the food web to consumers at a higher trophic level (Macintosh, 1984; Smith III et al., 1991). Thus, some studies seek to inventory and understand the malacofauna composition associated with mangrove-roots (Jiang \& Li, 1995; Márquez \& Jiménez, 2002; Cedeño et al., 2010; Acosta Balbas et al., 2014), highlighting the importance of these as consolidated substrates for survival and maintenance of estuarine biodiversity. With this perspective, the present note characterized the malacofauna associated with roots of Avicennia schaueriana of the hypersaline and inverse estuary, highlighting variations in abundance and diversity along a salinity gradient and different seasonal periods.

This research was conducted during the low tide in the estuary of the Casqueira River (505'37" S × 36 32'21" O), located in Macau city (Rio Grande do Norte state, Northeast, Brazil)
(Figure 1). This environment is characterized by being hypersaline and inverse with a salinity that decreases as approaching the river mouth of the sea.

Sampling was performed per month in March and May (rainy period) and September and November (dry period) in 2012, totaling four campaigns of data collection. Three sampling stations were delineated along the course of the estuary. At each station 3 transects of 10 meters were placed parallel to the margin, and for each of them 3 sample points were randomly selected. At each point, one pneumatophore sample of $A$. schaueriana was obtained.

A total of 108 samples were stored in plastic bags containing $4 \%$ formaldehyde and subsequently passed through a screening process,

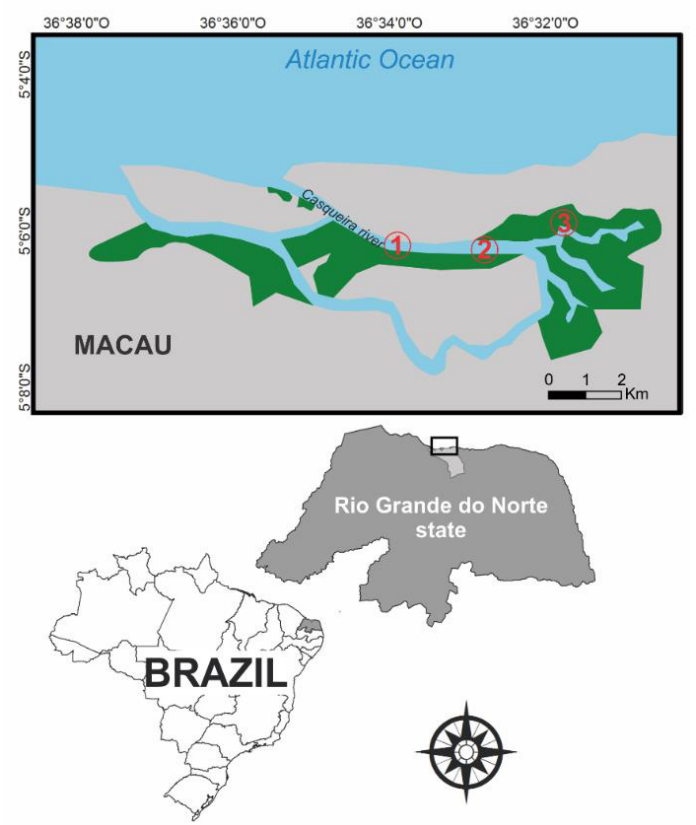

Figure 1. Geographical representation of the study area and sampling stations 1,2 and 3 . 
with identification of the associated specimens with the lowest possible taxonomic level. To verify if there were differences between the community of mollusk mangrove-roots associated with the sampling stations and the seasonal periods, an ANOVA test was performed.

A total of 171 specimens was recorded, belonging to 10 species, 7 families, and 9 genera of the Bivalvia and Gastropoda classes (Table 1). Among the gastropods, the family Pyramidellidae was the most representative in the number of species (3 spp.), followed by the family Caecidae (2 spp.). Among the bivalves, the Mytilidae family was the most abundant with 82 specimens of the Brachidontes exustus (Linnaeus, 1758) (Table 1).

The abundance of the specimens differed between the seasonal periods analyzed $\left(\mathrm{F}_{1.36}=4.45\right.$, $\mathrm{p}=0.01$ ), with the highest number of individuals recorded for the rainy season (91 individuals). Species richness was also higher for this period (10 spp.) (Table 1).

The abundance of mollusks also differed among the sampling stations $\left(\mathrm{F}_{1.36}=4.479, \mathrm{p}=0.02\right)$. With a posteriori Tukey test, it was observed that stations
1 and 3 were significantly different since they were the most distant and dissimilar with respect to the salinity gradient.

This is the first study that analyzes the mollusk composition associated with roots of Avicennia schaeuriana. Surveys have already been conducted with congenre $A$. marina (Schrijvers et al., 1996; Morrisey et al., 2003) in mangrove areas of Kenya and New Zealand. The number of species found in the roots of $A$. schaueriana was much lower than that reported in other studies with mangrove roots of the Rizhophora genus (e.g. Márquez \& Jiménez, 2002; Acosta Balbas et al., 2014) which together with A. schaueriana forms the mangrove forests of the Brazilian Northeast. This fact may be largely related to the smaller size of this root when compared to other species, but still the significant presence of mollusks in this microhabitat is observed, which demonstrates the great potential of these roots in offering shelter and protection for these individuals. Bivalves, following a pattern observed in studies conducted in this type of environment, were more abundant than the gastropods (Acosta Balbas et al., 2014; Cedeño et al., 2010). The dominance exerted

Table 1. Abundance of individuals per species in sampling stations and seasonal periods.

\begin{tabular}{|c|c|c|c|c|c|}
\hline \multirow{2}{*}{ Clade } & \multicolumn{3}{|c|}{ Sampling station } & \multicolumn{2}{|c|}{ Period } \\
\hline & I & II & III & Rainy & Dry \\
\hline \multicolumn{6}{|l|}{ Class Gastropoda } \\
\hline \multicolumn{6}{|l|}{ Litorinomorfa } \\
\hline \multicolumn{6}{|l|}{ CAECIDAE } \\
\hline Caecum ryssotitum Folin, 1867 & 7 & 4 & - & 8 & 3 \\
\hline Caecum johnsoni Winkley, 1908 & - & 1 & - & 1 & - \\
\hline \multicolumn{6}{|l|}{ Neogastropoda } \\
\hline \multicolumn{6}{|l|}{ COLUMBELLIDAE } \\
\hline Parvanachis obesa (C. B. Adams, 1845) & 18 & 2 & 4 & 8 & 16 \\
\hline \multicolumn{6}{|l|}{ Heterobranchia } \\
\hline \multicolumn{6}{|l|}{ PYRAMIDELLIDAE } \\
\hline Turbonilla fasciata (d'Orbigny, 1840) & 10 & 4 & 1 & 15 & - \\
\hline Folinella robertsoni (Altena, 1975) & - & 5 & 4 & 8 & 1 \\
\hline Odostomia sp. & - & 1 & - & 1 & - \\
\hline \multicolumn{6}{|l|}{ Class Bilvalvia } \\
\hline \multicolumn{6}{|l|}{ Pteriomorphia } \\
\hline \multicolumn{6}{|l|}{ MYIDAE } \\
\hline Sphenia fragilis (H. \& A. Adams, 1854) & 6 & 2 & 1 & 7 & 2 \\
\hline \multicolumn{6}{|l|}{ MYTILIDAE } \\
\hline Brachidontes exustus (Linnaeus, 1758) & 33 & 18 & 31 & 34 & 48 \\
\hline \multicolumn{6}{|l|}{ OSTREIDAE } \\
\hline Crassostrea rhizophorae (Guilding, 1828) & 2 & 1 & 1 & 3 & 1 \\
\hline \multicolumn{6}{|l|}{ Heterodonta } \\
\hline \multicolumn{6}{|l|}{ VENERIDAE } \\
\hline Anomalocardia flexuosa (Linnaeus, 1767) & 10 & 4 & 1 & 6 & 9 \\
\hline Total Abundance & 86 & 42 & 43 & 91 & 80 \\
\hline Relative abundance (\%) & 50.3 & 24.6 & 25.1 & 53.2 & 46.8 \\
\hline Richness & 7 & 10 & 7 & 10 & 7 \\
\hline
\end{tabular}


by the bivalve can be explained by the strong bonding mechanism to the root by cementing or by the byssus thread, conferring greater resistance to these organisms in function of the high dynamics of the estuarine environment.

The highest species richness and abundance of organisms in the rainy period allows inferences about the importance of the estuarine water cycle in regulating the biodiversity of these environments. The increased nutrient input as a result of rainfall should contribute to the increasing diversity of mollusks associated with the roots of Avicennia schaueriana.

The malacological fauna supported by the roots of A. schaeuriana constitute a range of organisms peculiar to this microhabitat, since some of the species found in this study were not sampled in other studies developed in estuarine regions of the Brazilian Northeast (e.g. Barroso et al., 2013; Lima et al., 2017), highlighting the particularity and importance of $A$. schaeuriana roots in harboring such species.

In general, the species $A$. schaueriana demonstrates an essential support capacity of benthic macrofauna, especially of mollusks, sustaining not only the taxonomic diversity but also the functionality of estuarine species. Thus, the importance of the maintenance and protection of the mangrove forests composed of $A$. schaueriana, as well as the need for more in-depth studies becomes evident.

\section{Acknowledgements}

We thank PIBIC/CNPq/UEPB (2013/2014) Program for the Scientific Iniciation scholarship granted to Jessica Lima. To Luis Carlos Damasceno for their assistance in the field.

\section{References}

ACOSTA BALBAS, V., BETANCOURT TINEO, R. and PRIETO ARCAS, A. Estructura comunitaria de bivalvos y gasterópodos en raíces del mangle rojo Rhizophora mangle (Rhizophoraceae) en isla Larga, bahía de Mochima, Venezuela. Revista de Biología Tropical, 2014, 62(2), 551-565. http://dx.doi. org/10.15517/rbt.v62i2.9803. PMid:25102639.

BARROSO, C.X., RABAY, S.G., MEIRELLES, C.A.O. and MATTHEWS-CASCON, H. Mollusks from two estuarine areas in Ceará State, northeastern Brazil, with new state records for four species. Check List, 2013, 9(3), 504-509. http://dx.doi. org/10.15560/9.3.504.

CEDEÑO, J., JIMÉNEZ-PRIETO, M., PEREDA, L. and ALLEN, T. Abundancia y riqueza de moluscos y crustáceos associados a las raíces sumergidas del mangle rojo (Rhizophora mangle) en la laguna de Bocaripo, Sucre, Venezuela. Revista de Biología Tropical, 2010, 58(Suppl 3), 213-226. PMid:21302531.

FELLER, I.C., LOVELOCK, C.E., BERGER, U., MCKEE, K.L., JOYE, S.B. and BALL, M.C. Biocomplexity in Mangrove ecosystems. Annual Review of Marine Science, 2010, 2(1), 395-417. http://dx.doi.org/10.1146/annurev. marine.010908.163809. PMid:21141670.

INSTITUTOCHICOMENDES DECONSERVAÇÃO DA BIODIVERSIDADE - ICMBio. Atlas dos manguezais do Brasil. Brasília: ICMBio, 2018.

JIANG, J.X. and LI, R.G. An ecological study on the Mollusca in mangrove areas in the estuary of the Jiulong River. Hydrobiologia, 1995, 295(1-3), 213 220. http://dx.doi.org/10.1007/BF00029128.

LIMA, S.F.B., LUCENA, R.A., SANTOS, G.M., SOUZA, J.W., CHRISTOFFERSEN, M.L., GUIMARÁES, C.R. and OLIVEIRA, G.S. Inventory of mollusks from the estuary of the Paraíba River in northeastern Brazil. Biota Neotropica, 2017, 17(1), e20160239. http://dx.doi.org/10.1590/16760611-bn-2016-0239.

MACINTOSH, D.J. Ecology and productivity of Malaysian mangrove crab populations (Decapoda: Brachyura). In: Proceedings of Asian Symposium on Mangrove Environment: Research and Management. Malaya: University of Malaya, 1984, pp. 354-377.

MÁRQUEZ, B. and JIMÉNEZ, M. Moluscos asociados a las raíces sumergidas del mangle rojo Rhizophora mangle, en el Golfo de Santa Fe, Estado Sucre, Venezuela. Revista de Biología Tropical, 2002, 50(3-4), 1101-1112. PMid:12947593.

MORRISEY, D.J., SKILLETER, G.A., ELLIS, J.I., BURNS, B.R., KEMP, C.E. and BURT, K. Differences in benthic fauna and sediment among mangrove (Avicennia marina var. australasica) stands of different ages in New Zealand. Estuarine, Coastal and Shelf Science, 2003, 56(3-4), 581-592. http:// dx.doi.org/10.1016/S0272-7714(02)00208-1.

NAGELKERKEN, I., BLABER, S.J.M., BOUILLON, S., GREEN, P., HAYWOOD, M., KIRTON, L.G., MEYNECKE, J.O., PAWLIK, J., PENROSE, H.M., SASEKUMAR, A. and SOMERFIELD, P.J. The habitat function of mangroves for terrestrial and marine fauna: a review. Aquatic Botany, 2008, 28(2), 155-185. http://dx.doi.org/10.1016/j. aquabot.2007.12.007.

SAMIDURAI, K., SARAVANAKUMAR, A. and KATHIRESAN, K. Spatial and temporal distribution of macrobenthos in different mangrove ecosystems of Tamil Nadu Coast, India. Environmental Monitoring and Assessment, 2012, 184(7), 4079-4096. http://dx.doi.org/10.1007/s10661-011-2245-x. PMid:21833734. 
SCHRIJVERS, J., FERMON, H. and VINCX, M. Resource competition between microbenthic epifauna and infauna in a Kenyan Avicennia marina mangrove forest. Marine Ecology Progress Series, 1996, 136, 123-135. http://dx.doi.org/10.3354/ meps136123.

SMITH III, T.J., BOTO, K.G., FRUSHER, S.D. and GIDDINS, R.L. Keystone species and mangrove forest dynamics: the influence of burrowing by crabs on soil nutrient status and forest productivity. Estuarine, Coastal and Shelf Science, 1991, 33(5), 19-32. http://dx.doi.org/10.1016/02727714(91)90081-L.

Received: 02 July 2018 Accepted: 18 June 2019 